\title{
To discuss new trend of information literacy from leisure reading behavior and experiences of junior high school students
}

\author{
Hui-mei Tsai \\ Librarian \\ National Cheng Kung University Library
}

Taiwan

\begin{abstract}
Information literacy education in school libraries is based on abilities of personal reading and learning. The research was used semi-structured interview in qualitative research to understand the reading behavior and experiences of junior high school students who are leisure reading lover. The analysis of qualitative data included both hermeneutic phenomenology and axial coding in grounded theory. According to research obtained, leisure reading behavior of junior high school students have several conclusion. First, The interesting content is the main motive. Second, the purposes of leisure reading behavior may divide into the tool goal and the non-tool goal. Third, internet is acting both important information source and channel. The analysis of leisure reading experiences of junior high school students have several conclusions. First, there are three kinds of reading styles that included comprehensive reading, tool reading and the non-tool reading. Second, participants often use internet communication software to exchange their reading information in internet reading. Third, participants often read datas which they searched or browsed, E-mail, internet literature and book description in the internet. According to research conclusions, this article discussed how to develop information literacy in junior high school students. These ways includes that use internet technologies to improve interaction, have library instruction classes depend on reading purposes, integrate reading information in school effectively and promotes software and hardware equipment in school to reduce the imformation divide. Finally, this article thought new trend of information literacy.
\end{abstract}

\section{Introduction}

Each stage all has its different importance in human development. Junior high school students is being placed in to escape from childhood and starting facing adolescence. The adolescence change is a continual process from the end of childhood to adulthood. Additionally, junior high school students begin to face the pressure of entering a higher school, the self-understanding, looking for the approbation of the peer-group actively. There are many external and intrinsic changes differently from the elementary school, so junior high school students need understanding and concerns very much. At present Taiwan approximately has 952,642 junior high school students (for the population proportion about $4.16 \%$ ) and plus senior high school students, population proportion is about $7.29 \%$. ( Department of statistics, Ministry of education, 2007). .Although the population proportion isn't high, according to 王嘉鈴(2001) analysis the result point out that, the teenager has quarter of the above proportion of the public library users. Therefore, teenager really is the important user in public library. Recently, there are more and more studies 
related to the teenager's reading. However, many reading behavior researches related senior high school students but often neglected junior high school students who just is in the puberty change. We know junior high school students reading behavior and experience a little.

Read behavior and experience are originally constructed by the reader and the text interaction process, reading can be treated as a highly personal experience. in the recent ten years, the usage of internet gradually becomes a part which many people live. Although Internet is a virtual world, it has many real behaviors to occur actually, for examples, online shopping, cyber-friendship, online reading, etc. Online reading is also one of the topic concerned by library and information science. What different and similar do paper and online reading that junior high school students read to have? What do junior high school students read online?

Finally, from viewpoints of education, with lifelong education promoting, the selflearning ability becomes one of personal basic abilities, however if persons could not develop a good reading habit in school education or family, most of them can't know how to use reading to learn in the life in adult's stage. This research try to discuss junior high school students leisure reading behavior and experience. Because leisure reading is often voluntary and less pressure, it should reflect reading motives and meanings of junior high school students. Only understanding junior high school students' reading behavior and experience, how they look for reading information, how library can do in reading service. We can more clearly understand the need of leisure reading information and information behavior in order to effectively promote information literacy.

\section{Research Purpose}

Research issues include leisure reading lovers of junior high school students, leisure reading, paper reading and online reading. Research purposes are as follows.

\section{To understand reading behavior of junior high school students and discuss different and similar between paper and online reading behavior. Reading behaviors include 5 topics}

1. Reading motives: understanding motives of causing reading.

2. Reading purpose : understanding effects or functions after reading.

3. Reading subjects: understanding preferences and needs of reading subjects.

4. Sources of reading information: understanding how to know reading information.

5. Channels of reading information: understanding channels that get reading information. 
To understand reading experiences of junior high school students in paper and online reading. There are 2 topics.

\section{Describing phenomenons.of junior high school students proceed with reading.}

2. Discussing relations between paper and online reading experiences.

\section{literature review}

Explaining relations of reading promotion and libraries to point out relations library young people service and junior high school students reading.

\section{Reading promotion and libraries}

Basis of 《中華民國圖書館年鑑.九十五年》statistics totally 732 junior high school libraries(room) in Taiwan, the building hides to measure 6,881,119 volumes, totally has $1,718,041$ persons to borrow to read during a year, borrow to read volume to count up to 2,763,768 volumes. Then, according to Ministry of Education 95 years of statistics, there are 952,642 persons in the junior high school, so average each junior high school student owns 7.22 books; Junior high school students borrow 2.90 volumes. On the other hand, 王嘉鈴 （民 90 ) also points out that the public library can gather statistics about the teenager goes into a building number, the average teenager has into $40.39 \%$ of building total number, so teenager is also important user in public library and worthy of devotion more manpower and resource to research.

However in school library, the development of library in the junior high school is always not enough, there is the professional staff's establishment in few schools, besides which, greatly all of the part depends on teachers or employees to come to conduct. Even some libraries(room) are only spaces but didn't provide a service, so for long time, library instruction classes and information literacy education can't concretely overall implementation in junior high schools in Taiwan. With the result that cause many students who go to university are unfamiliar with library resource. In order to improve this situation, library instruction should carry out since the childhood. The elementary school should gradually guide and teach school-children learn " how to reading", and after going to the junior high school, in addition to learn reading, should also let students know " reading to learn". Furthermore, library should combine services and reading to develop students' self-learning ability.

"The library development White Paper in Taiwan"(圖書館發展白皮書, 2000) speaking of the five greatest functions of library having two items relate to reading. One is education includes providing teaching materials, social education and life long learning promotion. The other is satisfying people usual information need and promoting proper recreation. Library not only play role of enriching a mind, but also the best public place to pursue progress and complete self-learning. Besides the library, the school is also the main organization that spreads information. Schools also depend on vast publishing and library to 
provide resources (吳美美，2000）. There are inseparable relations between learning, library, school and reading.

Reading to the person, in addition to being the method that learns a new information, can be recreation, interest, or even is a part of living; Reading to library, in addition to being a service, is also the impression of "mine of knowledge, be happy to learn" that symbolizes library to the person. The reading promotion has been one of important direction in library. Reading is exactly the source that makes human knowledge continuously spread and created, so library believes deeply the value and strength of reading. Reading to society, in addition to promoting cultural spirit, is also a foundation stone that establish life long learning. Because the importance of reading, International Reading Association(IRA) formally established in January, 1956. The aim of IRA is that raise quantity of reading education through researches of reading process and teaching skills; Meetings and publish journals and other publications to help IRA become a place where disseminate and communicate reading researches in order to raise the level of people reading and writing in all of the world, and encourage people to develop reading habits in whole life.

In Taiwan, the library currently often push reading activities that have book clubs, new book recommend, book circular car service, etc. Recently, there are book clubs hold for junior high school students in order to develop to listen, respect, tolerate, diverse spirits through reading, discussion, group activities, handicraft book creations, etc (民生報，2004). Furthermore, the Government Information Office, Taiwan carries out "the primary and junior high schools good leisure reading books recommend"(中小學生優良課外讀物推介) from 1982 up to the present. It provides good leisure reading books recommend lists for related education departments every year. Its purpose is constructing high-quality reading environment for new generation and breeding humanities literacy of modern citizen by promotion of good books. (邱各容, 2002).

\section{Reading and information literacy}

Reading is a important part of education. In order to push "education reform action project"(教育改革行動方案), Ministry of Education, Taiwan, implement "國民教育階段九 年一貫課程" in 1991 from elementary school to junior high school. Its curriculums target particularly emphasize that using science and technology and information to stir up one's own initiative investigation and study spirit and develop abilities of independent thinking and work out problem. (Ministry of Education, Taiwan, 2001) Emphasizing the ability of information learning by oneself . Council of Cultural Affairs also declare 2,000 years as "children reading year". Besides, " library development three years plan, Ministry of Education "(教育部圖書館事業發展三年計畫) is from 2002 to 2005 and promote civil reading and raise information literacy that is one of the seven greatest targets. (吳英美, 2002).

In recent years, in order to respond advancing in information science and technology, with information changing fast, internet without distance, so developing abilities of personal information literacy becomes public consensus, and abilities of the information literacy is laid that correct methods of searching data and good reading habit. National Central Library, Taiwan prints the series books of the library and information literacy in 1999. 《Library instruction_ junior high school 》(圖書館的利用_國民中學篇), one of series books, is written by profession 郭麗玲 for junior high school. 《Library instruction_ junior high 
school $》$ is to promote all kinds of resource in library and effectively provide a guidance in self-learning for junior high school students. Furthermore, National Central Library longdistance learning center(http://cu.ncl.edu.tw) makes use of education by the information of the video teaching to promote library and information instruction. Long-distance learning center has variety curriculums of information literacy. "The teaching method of the information literacy " or " learning how to learn" is to learn reading, thinking, and find data. Let each school has a sound library media center and professional librarian. (吳美美,2000).

To sum up, the library teenager serves is still growing. Among them how to push junior high school students reading, not only the library should put into concern, but a part of the national reading exercises. It is worthy of value in library and education. Junior high school students how would like to start to turn over a book and get fun from reading, but isn't addicted to television or internet. Each parent concern it; On the other hand, the school library how attract junior high school students to read, don't just read while making homework or studying, but continue the reading after the class. It is more worthy of considering.

\section{Research method and interviewee}

\section{Research method}

Semi-structured interview was used in this research. Semi-structured interview is one of methods in qualitative research. The main reason of adopting a quality research method is that quality research can verstehen or comprehend personal experiences and meaning construction of research objects. The researcher made an explanation that is in interviewee living story and meaning construction by personally experience .(陳向明，2002).

Semi-structured interview is one of methods in interviews. It between open-ended and structure interviews. The main reason that uses the method of semi-structured interview lies in this research. This research want to understand reading behavior and experience deeply in junior high school students, so it use interview method to let the interviewee adequately speak out personal experience by themselves language. In the meantime, generally speaking, experiences are always presented by speaking and description.

\section{Interviewees}

The interview use purposive sampling. the principle of purposive sampling is junior high school students who are from 12 to 16 yeas old have abundant reading experience. They have the ability of experience of the expression reading and would like to participate in this research. The men and women's sampling ratio is as far as possible average.

While using a purpose sampling to choose an interviewee, in addition to the approval that consults an interviewee, for helping reference (Gatekeeper) determine objectively an interviewee indeed is a leisure reading lover, so according to researches(游常山, 2002; 黃 育君, 1996 ; 陳明來, 2001)understand that junior high school students reading time about 1.3 to 3 hours for a week. As long as a junior high school student who read more time than average is thought as a leisure reading lover in the research. After gatekeeper recommended, carrying on interview. Gatekeeper is including teachers, librarians and interviewees. 
On the interview number with reach the saturation degree of data analysis. This research interviews, data processing and analysis was carried on in the meantime. Each new interview data is analyzed with previous data result again. Through continuously circulation analysis and comparison to reach the saturation of data analysis. In this research, while interviewing to the 11 and 12th interviewee, data analysis have already presented a saturation degree. Then, carrying on the interview of the 13,14th interviewee at this time to confirm results of data analysis and process. Interview detailed list, please see table 1.

Table 1 Interview detailed list

\begin{tabular}{|c|c|c|c|c|c|}
\hline Number & $\begin{array}{l}\text { Time (First \& } \\
\text { second) }\end{array}$ & Place & Nickname & Degree & Sex \\
\hline 1 & \begin{tabular}{|l|}
2003.5 .7 \\
2004.12 .11 \\
\end{tabular} & Kaohsiung & patty & 3 & female \\
\hline 2 & 2003.6 .1 & Taipei & 小高 & 3 & male \\
\hline 3 & 2003.6 .1 & Taipei & 玲玲 & 3 & female \\
\hline 4 & 2003.6 .4 & Taipei & 小文 & 3 & male \\
\hline 5 & \begin{tabular}{|l|}
2004.4 .1 \\
2004.7 .20 \\
\end{tabular} & Taipei & 小可 & 2 & female \\
\hline 6 & 2004.4 .1 & Taipei & 小成 & 3 & male \\
\hline 7 & 2004.12 .6 & Puli & 小容 & 1 & female \\
\hline 8 & 2004.12 .6 & Puli & 小米 & 1 & male \\
\hline 9 & \begin{tabular}{|l|}
2005.01 .06 \\
2005.01 .07
\end{tabular} & Kaohsiung & 小如 & 1 & female \\
\hline 10 & \begin{tabular}{|l|}
2005.01 .06 \\
2005.01 .07
\end{tabular} & Kaohsiung & $\mathrm{LiLi}$ & 1 & female \\
\hline 11 & 2005.01 .14 & Kaohsiung & 小芳 & 1 & female \\
\hline 12 & 2005.01 .24 & Kaohsiung & 藍蹤 & 2 & male \\
\hline 13 & 2005.02 .05 & Kaohsiung & 婉兒 & 3 & female \\
\hline 14 & 2005.02 .05 & Kaohsiung & 晴朗 & 3 & female \\
\hline
\end{tabular}

\section{Conclusion}

These leisure reading interview data are used in main three parts: (1) leisure reading behavior in junior high school students, (2) leisure reading experience in junior high school students, (3)Compare paper with online reading in junior high school students. Analysis and interpretation of data are used hermeneutic phenomenology to understand essences of leisure reading experience, and took axial coding in grounded theory to analyze data.

This research purposes and conclusions as follows:

\section{Reading motives—why want to read leisure books?}

Motives of leisure reading in junior high school students synthesize paper and online reading, it can be divided into"active" and"passive" two major types. Active includes interesting content, mediate boredom, feel interest or curious, enrich self, obtain sense of achievement and satisfy imagination or expectation. The content is interesting in addition to the interest of plot or story, also because of the content of book certain one partial attracted or moved them.

\section{$Q$ ：爲什麼你喜歡三國演義？}


小米: 我覺得這段歷史很有趣, 比較多很有名的人物出現在這個時代中, 然後還有描寫他們很庽害的地 方，就是諸葛亮借東風、關羽很英勇，我很欣賞他們。（小米，130-132）

The fun from leisure reading also often let the person forget time passage, let the person indulge therein. The most obvious is that some junior high school students think leisure book isn't as rigid as school course book or textbook. leisure reading content is often fascinating.

入迷就可以, 印象最深刻的是, 有一次, 中午去書店看金墉的小說, 一直站著看, 到晚上十點, 整整看 了十個小時, 也沒有休息，也沒有去上廁所（小文，71-72）

很容易沈迷在裡面, 因爲課外書比較有趣阿, 比課內書, 我對課外書比較有興趣。(Patty1-2, 354357)

The interviewee carries on the motives of leisure reading sometimes isn't active, but passive motive, including lessons to specify or request with parents. However, even if it come from passive reading motives. As long as reader can feel the "active" motives above, reading motives can also turn into active from passive.

應該是從學校 (小學) 開始, 那時候老師會辦課外書展活動, 老師會常常要求學生看課外書, 然後就在 教室後面就放一個兒童的雜誌阿, 那時候, 就是跟國文什麼有關係就是, 一開始不是很想要看, 一開始 是因爲閒閒沒事作, 老師有時後不在, 就無聊拿起一本書來看, 應該是因爲課本很乏味吧!（晴朗, 113-120)

Leisure reading motive is often active and interesting content is a main motive in interviewees, so this can reflect that leisure reading is relaxing and recreational.

\section{Reading purposes}

Reading purposes can be divided into "tool" and"non-tool" two major types. Tool purposes have Strengthen studies, work out a problem and relieve pressures. Interviewee's motive maybe enrich self or obtains sense of achievement, and then create tool purposes after reading. Sometimes, interviewee's motive maybe feel interest or curious , and then absorbed information by accident.

嗯, 應該是這樣子, 要學㫘要不同的角度看事情, 嗯, 去瞭解別人的想法是一件很有趣的事情。但不只 如此, 有時後看書的時候, 是問題剛好在那邊了, 但隨著書愈看愈多, 就會累積一些不同的經驗, 某些 事情, 是以前根本沒想過、沒遇過的, 但是因爲你有看某一本書, 你會在你腦中先記下這件事, 或許不 是現在, 但等到某一天, 當你真的遇見這件事情時, 你就可以參考別人的作法, 或者是去瞭解另一個人 的想法。(小成, 162-170)

Besides tool purposes, leisure reading has non-tool purposes, including obtain amusement and kill time. In the process of reading, interviewees expect to obtain some fun or perhaps not feel bored from leisure reading.

金庸是把一些人物、動作描寫得很活、很清楚, 拖爾金在書裡面創造很多科幻、魔幻的東西, 像是他一 直想一直想，想出精靈文之類的。（藍蹤，140-141） 
According to interviewees are different from reading motives, they purpose also has difference. For examples, if motive is enrich self and read leisure books related lesson, the purpose is because of wanting to strengthen studies performance; If motive is mediate boredom and read leisure books to kill time, the purpose is always non-tool.

\section{Reading subjects}

Reading subjects can be divided into studies related and non-studies related, and includes various types and contents. It depends on personal favour. These studies(白璐, 民 62 ; 水心, 民 66 ; 黃育君, 民 87 ; 陳明來, 民 90 ; 游常山, 民 91 年; 陳玉棠, 民 91 ; 孟緩, 2003) explained reading subjects from types(books, cartoon, journal,etc.) or content subjects(love, business, fantasy). This research conclusion also find that interviewees reading types and subjects are broad, including mental state, science fiction or story, history, geography, romantic novel or story, cartoon, art, original work in movie or television, etc.. This is similar to former research results.

Studies related subjects are only limited by the studies related leisure books that junior high school students" self-moving" read, therefore don't include textbook etc. "Nonstudies related subjects " are extensive, can be divided into 3 types: "every kind of literature work", "popular vogue", "life philosophy" that according to personal favour and dissimilarity. On the life philosophy, it is not necessarily the interviewee's personal interest. They are placed in puberty and in the process that childhood turn into adulthood, so they are usually worry about interpersonal relationship, entering higher school pressure, self-esteem and selfapproval. Therefore, they have quite a few need to the subject of "life philosophy" and hope to get guideline, edification and encouragement.

LiLi : 還有大啓示哪種, 他就一句靜思語阿, 然後前面就會有些故事讓你知道！滿喜歡類似前面有各小 故事或者寓言，然後看完，就會有些啓發或感動之類的（47-49）

\section{Sources of reading information}

This research divided the interviewee's reading information sources into "active search", "mutual interchange " and "passive receive" three kinds of methods. "Active search" is interviewees make use of different information ways to search and seek, while finding or getting information sources by oneself. "Mutual interchange " is that interviewees and peergroup interact each other and get information sources. "Passive receive" is interviewees receive all kinds of information sources by accident. Interviewees may make use of three kinds of different ways to know book news in the different channels.

喔! 讓我想想看, 好像是小時候有一次, 媽媽要去辦事情, 就把我跟姊姊丢在書店, 然後我跟姊姊兩個 人, 就自己坐在書店的矮椅子上, 應該那時候是在兒童區吧。喔! 有時後是跟姊姊一起去, 或者姊姊也 會帶一些書回來家看, 有時後媽媽出去辦事, 就會留我一個人在書店, 我就可以在書店看看書 (小可, 123-130)

It is quite important source that the peers' oral communication or exchange through internet in junior high school students. They have closer interaction with the peer than the reader of other age ranges obviously. These methods that sharing and exchanges, can be 
divided into two main parts: Each other" borrow or exchange books" and " sharing or exchange books". Peer-group in junior high school includes similar to their age and often have the personal interaction in life, so good friends, sisters and relatives, classmates, cram school classmates and friends, net friends are peer-groups.

我是我們班在看, 然後他們就會問我說：入, 這本書不錯耶, 那你要不要看, 我就會說：我考慮一下, 因爲我父母可能會不太同意我看, 之後他看完之後, 我就會說: 那我先看看, 結果我一看若沒有興趣的 話, 我就會說：我不要看, 謝謝。然後他還會去問他最好的朋友, 要不要看。 ( LiLi, 193-196)

In addition to the oral communication, junior high school students also often use internet to carry on exchanges of book news. Internet covers E-mail, software of the network communication (as MSN, Skype, on-line game etc.), netnews, network discussion area and message board.

會阿！比較好的朋友，會寄 E-mail，好朋友阿，還有同學（小如，295-297）。

\section{Channels of reading information}

The ways of the interviewee's information seeking are diverse. Interviewees will look for books toward the different channels, but everyone have his own often or a little used channels. It presents different preference to the utilization of channels.

This research analysed channels of leisure reading information by "location" and "method" two points. On the "location" has the family, bookstore, rent bookstore, school, public library, book exhibition, hypermarket and internet. This research points out that school provided many channels, like class and class stack, the school store/student affairs office. It is seldom pointed out in literatures. The books and book lists of these locations in school are passed round for perusal that is playing an important role for obtaining leisure books.

On the "method" includes oral asking a person, using classification, browsing, searching a computer and personal memory linking. Five kinds of methods is carried on the behavior of finding books or articles.

Finally, the internet is an important information source and channel. Interviewees often deeply make software of the network communication as the tool that exchanges reading information

$Q$ ：你覺得網路上有一些可以看的課外讀物？

patty：小說吧

Q:你都去哪一個網站看?

patty：家族，像是 yahoo 的家族，家族的成員他們自己寫的（patty1-2，267-272）

嗯，網路阿，有阿，我都會上網看看有什麼新書，然後記下來，去書店找（小可，134）

\section{The relation of leisure reading and junior high school students' life experience}

Different style readers expresses special features and it can be divided into extensive reading style, non- tool reading style and tool reading style. The same relations are that the favour of books depend on personal judgment, books cause inspiration and introspection actively, readers personal experience of books. Special features are that extensive reading 
style accepts each kind of book easily. Its reading motive, purpose and topic are also more extensive.

嗯, 我幾乎什麼都看, 文學方面, 我比較喜歡中國古典文學, 、、、嗯, 像到書店, 看到一本書不錯, 就把他抓起來看（小文，25；46）

Non- tool reading style emphasizes satisfaction of emotion or curiosity, therefore they usually cannot help but repeatedly read story details that particularly attracts them. The subjects of reading are often focused on some personal favorite, so they often have crazy passion for a certain subject, like knight errant, romance fans or science fiction.

比如說漫畫阿, 我就會去找少女漫畫阿; 如果是說普通的書喔, 我就會找比較適合我年紀的看的, 不會 去找什麼理財的阿, 這種不適合我看的, 就不會看, 就是那種比較有故事性、虛構的, 、, , patty： 喜歡的就會看；不喜歡的一點興趣都沒有！。（patty，85-88；105）

Tool reading style clearly wants to have gains from books, therefore the relation of reading and life is quite close and practical. Reading motive is sometimes because of enrich self or obtain sense of achievement in order to work out some problems; sometimes because of feel interest or curious. They expect to get some inspiration, common sense or knowledge from books before reading.

覺得還好耶, 漫畫書好像沒有什麼。不過, 如果是那種可以增加知識的, 然後就是有些可以增加科學知 識的書, 但是怕字太多, 就改成用漫畫, 讓人比較容易瞭解的書, 這樣更快增加吸收的, 那種我就喜 歡。我覺得, 少女漫畫我不喜歡, 覺得有點虛構, 好虛構的感覺。而且, 看那種書好像有點浪費時間 耶。看書的時候至少總希望對自己有些意義，有些感動（小容, 229-240）

The relation of paper and online reading. It can be divided into "studies and online reading", "personal interest and online reading", "paper and online reading are complementary" and "reading of the online literature". From data analysis, we can know that interviewees often read information from personal searching and casual browsing, E-mail, online literature (full text or parts of content), brief introduction of books(the book title, author and cover ), ePaper, multi-media, network communication, network discussion area and message board, playing PC games on the internet. Interviewees hardly use BBS or read electronic journals and e-books.

現在比較少用 E-mail 跟同學或朋友聯絡了, 都是用那種比較新的, 像是「即時通」來跟同學聯絡, 那 麼假如說開「即時通」, 對方不在的話, 就改用寄信的, 寄到他的文件夾, 他可以去看, 如果他本人有 在上面，有急事的話，再用「即時通」跟他聯絡。（小米，189-192）

嗯, 我覺得那是一種反向的思考, 在網路上就是另一個虛擬的世界, 你可以扮演, 甚至是創造一個你喜 歡的角色, 、、、, 因爲, 我覺得, 在網路上玩遊戲, 很大一部份是可以抒解壓力, 因爲有些人, 可能 在現實生活中有些壓力, 但是不知道如何去消除, 像是有些人會選擇去打球, 上網玩遊戲也是一樣, 他 能夠消除某些壓力, 而且網路遊戲是這樣, 只要你願意花時間在上面練, 你的等級就會提升, 感覺上就 會覺得有進步, 甚至是比別人庽害, 得到一些現實生活中得不到的滿足, 、、, 在最瘋狂玩線上遊戲 的時候會, 哪時候, 還偷偷不睡覺在玩, 然後上網去找遊戲網站, 每一個都看, 看又什麼密技。（小 成, 195-206) 
Finally, because junior high school students do not have enough life experience, the result is from leisure reading, if interviewees have the purpose of tool type, they easier feel combinative with life; Unless the purpose of tool type, greatly part of interviewees do not easily speak out concrete combination with life. Therefore, interviewees would rather "learn" or "feel" life experiences once hasn't yet from books, than get relative life experiences from books. Then, they can immediately introspect or keep in memory to wait for some affairs to awaken that time of reading experience.

\section{The relation of paper and online reading}

This research finds that paper reading behaviors are similar to online reading behaviors, including reading motive, purpose, subjects. There are a little differences between paper and online reading behaviors. Furthermore, Internet is an important leisure reading source and channel.

On the control of book content, interviewees completed mainly through searching and reading these two process. Because internet becomes one of leisure reading information sources and channels, in the meantime, internet has close interaction with other information sources and channels, this research compare behaviors of paper and online reading and the main detection is that the biggest advantage of paper is easy to read; the biggest special feature of internet is easy to search. Therefore, junior high school students usually searched leisure reading information first on internet, and then looked for printed-book again to carry on complete reading. It also appear search data prefer to internet and read the book prefer to paper. In other words, interviewees use internet first to search whether internet have the related solution of problem, if it could not be found, then interviewees will go to libraries or other channels to look for help from books. Therefore, on reading behaviors, paper and online reading can be said to be complement each other.

婉兒：我都是用 yahoo，我覺得滿方便的

$Q$ : 都可以找到你要的嗎?

婉兒：可以，可是有時後會找不到。

$\mathrm{Q}$ : 你會怎麼處理

婉兒：試試別的方法，比如說可能是關鍵字有問題，再把它句子縮短來找，

$Q$ : 如果還是找不到呢

婉兒：那麼就找書

$Q$ : 哪裡的書?

婉兒：家裡的、或圖書館

$\mathrm{Q}$ : 所以你今天要找資料的話?

婉兒：會先用電腦找, 看看有沒有相關的資料, 如果找不到再去用圖書館的找。

$Q$ ：那你覺得如果直接去圖書館找資料，這樣對你的問題會不會比較有直接的幫助？

婉兒：應該是還好吧！因爲我很少還要去圖書館找資料, 只要上網通常都找得到（婉兒，132-148）

As for books can be seen full text on internet, interviewees will choose to browse content directly. Then, it depend on personal acceptance degree of online reading to choose to skip or read amply. If interviewees like book content very much, they will browse or purchase the printed-book again. 


\section{Suggestion}

This research discussed reading behavior and experience in junior high school students. Studying content is related to the topic of the information behavior, it can touch on "information need and response" and "information use". In other words, information need and response surround the issues of reading behavior, this research discussed reading motive, purpose, subjects, information sources and channels to answer; Information use are analyzed by reading experience, including different reading styles, the relation between reading and life experience, and the relation between paper and online reading.

The library wants to promote effectively information literacy in junior high school form understanding information behavior of junior high school students. Reading behavior and experience are exactly important part of information behavior of junior high school students. By the results of this research, it provided several suggestions to expect to help develop information literacy of junior high school students. These suggestions are included using internet technology to promote interaction, carrying on library information education depended on the different reading purposes, integrating school reading information availability, improving software and hardware in the school to reduce digital divide.

\section{Using internet technology to promote interaction}

Internet becomes an important information source and channels in junior high school students, so the library should makes use of internet technology to promote interaction with junior high school students.

On the information channels, this research found the reason that interviewees didn't use computers of the library to search books, it is because there are few computers and not particular books to read, interviewees did not know how to search books. Therefore, the library should prepare enough computers for users and more humanistic on the design of computer. In other words, the library should design search interface from usage need of junior high school students. For example, on the information sources, interviewees get book news from "active search", "mutual interchange " and "passive receive" three kinds of methods, the design of library web page and webpac should provide different information sources for users. On active search, the library provide users with more column of the search relative to books and browsing ways, for example, searching and browsing of new books. On mutual interchange, the system has to let users recommend books, have discussion area or Q\& A to help staff and reader interact. On passive receive, besides the notice of reader's book borrow and return, the system should let users build up personal interest files by personal favr to select information and inform users actively.

Furthermore, network communication software(as MSN or Skype) becomes an important communication tool between junior high school students and their friends, hence, the library can also use the software of the network well and apply for a public ID, and then announce this ID on the web page. The library make use of the software of the network online to immediately answer users' various library service questions and promote interaction with junior high school students. 


\section{Carrying on library information education depended on the different reading purposes}

School library in addition to provide plentiful resources for teachers and the students in school, the most important is that teach junior high school students library information education in good time. School library should let junior high school students have basic knowledge about classification and catalog. It is the beginning of information literacy education.

To implement library information education, in addition to when students meet the problem of the library use and librarian promote service in good time, librarian had better teach systematically in class. It is the foundation that junior high school students use the library well and carries out information literacy education as early as possible.

\section{Integrating school reading information availability}

On information channels of interviewees, this research found that in addition to school library, junior high school students also look for leisure reading information from class and class stack, the school store/student affairs office. In order to effectively provide junior high school students to get reading service, school library in addition to appropriately do book reservation, it also needs to consider how to integrate reading information in school to become information center. Therefore, school library actively cooperates with teachers and provides books for class stack and reading party, or keeps in touch with school store/student business office. School library can know the reader's favor from the situation that junior high school students order each kind of books in school, and then it can become a purchasing reference.

Furthermore, because junior high school students have their characteristic in development of the mind and body, they need reading information of mind and body development, emotion management, life philosophy and career planning. Therefore, school library can cooperate with department of mental counseling service in school and give relative books list for department of mental counseling service for planning curriculum. School library can delivery these books list in class and hold a topic book exhibition with a curriculum for effectively promoting collection.

Finally, we can effectively know students' reading need through integrate the reading information in school and combine these need with collection and information literacy education. It more easily integrate into the life of junior high school students and reach the effect of half effort and double results.

\section{Improving software and hardware in the school to reduce digital divide}

Internet plays an important information channel and source. Using internet must have some hardware equipments and adequate instruction, but few interviewees didn't have a computer at home. They must use a computer to do online reading and search reading information in other places.

\section{我們家沒有電腦怎麼下載！(小如，272）}

The school is an educational organization and School should provide a fair learning environment for each student and let every student have chance to get in touch and use a 
computer from different social and economical background. School improves software \& hardware equipment and matches with related information literacy education to reduce digital divide. Information literacy education let students be able to know search on internet, make out web page content, refuse a not appropriate web page, and to know how to handle the information tool and technique.

Besides, some families probably have a computer, but limit a student use a computer. This depends on the attitude of the parent about junior high school students use a computer, and whether someone can properly guide junior high school students to use a computer. Consequently, school should make effort to implement information literacy education of computer and internet.

我通常都是看紙張的書, 因爲在網路上看, 要用視力, 媽媽會限制我們每次上網是一個小時或牛個小 時, 媽媽很重視我們的視力, 都是要看 (紙本) 書的, 大部分都是看 (紙本) 書的 (小米, 205-207)

\section{New trend of information literacy}

This article got reading behaviors and experience from junior high school students' leisure reading motives, purposes, subjects, information sources and channels, and described the relation between reading and life experience. This article considered new trend of information literacy from information behavior of reading.

\section{Making topic books list for different reading styles}

Library(especially public library) includes users of different age ranges, in the meantime, collection are various. Junior high school students are one of important users of public library, therefore, how effectively promote collection and attract junior high school students to use and find resources conveniently in public library. It is very worth consider of problem.

This research analysis paper reading experience and divide into extensive reading style, non- tool reading style and tool reading style. Three kinds of interviewees who have difference in reading motives, purposes and subjects, therefore, the library can make appropriate topic books list for different reading styles to effectively promote collection.

For extensive reading style, library should possibly provide every kind of book news and different topic books list, including every kind of tool or not- tool books list for choice. For tool reading style, the purposes of reading are often tool purposes. This research divided purposes into strengthen studies, work out a problem and relieve pressures, therefore, the library can match with the tool purposes and make topic books list for different academics or living problems to effectively combine with the life of junior high school students, and then satisfy the reading need of junior high school students.

For non- tool reading style, their reading purposes often obtain amusement and kill time, therefore the library can select work, such as literature, novel and cartoon, for junior high school students. Library can provide applicable books that readers have interest. 


\section{Information literacy must merge with activities of daily livings and learning}

Now is the age that paper and online resources are coexisted and complementary. Information literacy can't ignore the development of control ability of paper resources. Paper resources provide many organizational and systematic knowledge, in the meantime, it is more clear in the management of content and table than online. Furthermore, paper resources are easily marked and browsed at any time, so it are still the important information source that people rely on for understanding any subjects or research.

On the other hand, due to the approach in digital times, plus changing with each passing day of computer science and technology with the fast renewal of network content, let online reading becomes a new reading trend. There are also more and more schools put content of course, teaching materials and homework on the internet gradually. School provide the access service of web page. It is convenient for student to review and practice at any time, therefore under this kind of trend, the establishment of high-quality e-learning environment becomes worth considering.

The establishment of e-learning environment is not only content of course with related the data put in the web page, but also have related software \& hardware and manpower longterm devoted, including computer room set up, computer in class, computer in library and maintenance system. The teacher is responsible for guide students correct use method, on-line interaction and discussion area, learning of test and self evaluation, the teachers and the students' suggestion to the e-learning environment and improvement are continuous process. According to the process of the continuous test, use and evaluation to establish e-learning environment that suit teachers and the students use in school. Information literacy education and curriculum can also play a cooperator and instructor in this the process of the work. Along with the progress of the e-learning environment, system renew information at any time. Let the teachers and the students can integrate into e-learning environment by information literacy education and curriculum and easily integrate teaching and learning information. Teachers and the students do not spend another time and effort learning new system. Elearning environment reach human and friendly interface, let information and learning become a part of life.

Ps. This article particularly thanks Profession Shan-Ju Lin CHANG who instruct Master thesis, and I can rewrite this thesis to publish.

\section{References}

Waples, D., Berelson, B., \& Bradshan, F. R. (1940). What reading does to people: A summary of evidence on the social effects of reading and a statement of problems for research. Chicago: University of Chicago Press

Strauss, A. \& Corbin, J. (民 86) 。質性研究概論（Basics of qualitative research: grounded theory procedures and techniques）（徐宗國譯）。臺北市：巨流。（原作 1990 出版）

水心（民 66，9月）。國民中學學生課外閱讀興趣硎究。教育輔導月刊，72（10），2-15。

王嘉鈴（民 90）。臺灣地區公共圖書館青少年服務現況與發展之探討。未出版之碩士論文, 國立臺灣 大學圖書資訊學研究所, 台北市。

台北市立圖書館中山及西園分館，開辦五種讀書會（民 93 年 4 月 18 日）。民生報，D4。

白璐（民 62，10月）。臺北市中學生課外閱讀興趣之調查研究。中原學報，2，84-115。 
邱各容（民 92, 4 月）。從優良課外讀物推介談國內的閱讀風氣。在國家圖書館主辦, 圖書館與閱讀運 動研討會第五場次, 台北市。

吳美美（民 89，5 月）。領航二十一世紀閱讀的重要文件--我看「圖書館事業發展白皮書」。全國新書 資訊月刊, 17, 3-5。

吳英美（民 91 年，5月）。圖書館事業發展三年計畫。國家圖書館館訊，91（2）=92，15-18。

林珊如、洪曉珊（民 88，6月）。網路書店使用者資訊行爲之研究。資訊傳播與圖書館學，5（4）, 21-33。

林珊如（民 91，12月）。網路使用者特性與資訊行爲研究趨勢之探討。圖書資訊學刊，17，35-47。

林珊如（民92，6月）。大學教師網路閱讀行爲之初探。圖書資訊學刊，1(1)，75-92。

孟緩（2003）。少年兒童閱讀規律研究。圖書館工作與研究，5（總 117），65-70。

郭麗玲（民 88）。圖書館的利用_國民中學篇。台北市：國家圖書館。

陳玉棠（民 92）。桃園縣立國民中學學生資訊需求研究。未出版之碩士論文, 國立臺灣師範大學社會 教育學系在職進修碩士班研究所, 台北市。

陳向明（民91）。社會科學質的研究。台北市：五南。

陳明來（民 90）。臺北市公立國中生課外閱讀行爲之研究。未出版之碩士論文, 國立政治大學圖書資 訊學研究所, 台北市。

教育部統（民 95）。國民中學概況。上網時間：民 96 年 4 月 01 日。網址： http://www.edu.tw/EDU_WEB/EDU_MGT/STATISTICS/EDU7220001/service/sts43.htm?TYPE $=1 \&$ UNITID $=93 \&$ CATEGORYID $=0 \&$ FILEID $=112834$

教育部國教專業社群網（民 93）。上網時間：民 93 年 11 月 6 日。網址：http://teach.eje.edu.tw/

國家圖書館（民 95）。中華民國圖書館年鑑.九十五年。臺北市：國家圖書館。

國家圖書館遠距學園（民93）。課程目錄。上網時間：民93 年 11 月 5 日。網址： http://cu.ncl.edu.tw/sys/class_index.php

游常山（民91）。中小學教師閱讀大調查。上網時間：民 93 年 5 月 10 日。網址： http://www.lcenter.com.tw/2002edu/article05-2.asp

黃育君（民 87）。青少年閱讀行爲與公共圖書館服務探討：以雲林縣立文化中心圖書館閱覽室青少年 讀者爲例。圖書與資訊學刊, 26, 54-78。

曾祥芹、韓雪屏 $(2002)$ 。國外閱讀研究。鄭州：大象出版社。

劉應琳（民 90）。閱讀研究：台大 BBS Books 版愛書人休閒閱讀之探討。未出版之碩士論文，國立台灣 大學圖書資訊學研究所, 台北市。 